\title{
MATERIAL/HISTORIC REALITY: CATCHING THE TRANSFORMATION. FROM A CASE OF APPLIED RESEARCH TO THE TRANS-DISCIPLINARY APPROACH TO PRESERVE ARCHITECTURE
}

\author{
A. Aveta ${ }^{a}$, B.G. Marino ${ }^{\text {b }}$, R. Amore ${ }^{\mathrm{c}}$ \\ ${ }^{a}$ Full Professor of Restoration at the University of Naples Federico II -aldaveta@unina.it \\ b PhD Associate Professor of Restoration at the University of Naples Federico II - bianca.marino@ unina.it \\ ${ }^{c}$ PhD Assistant Professor at the University of Naples Federico II - raffaele.amore@ unina.it
}

KEY WORDS: Interdisciplinary survey, critical knowledge, restoration methodology, identity

\begin{abstract}
:
The present paper aims at dealing with some issues of knowledge of the architectural heritage. Given the increasing use of the innovative technologies in the field of the cultural heritage it is important to focus on their usefulness and potentialities in order to the conservation project management. The role of the new survey techniques and the accurate representations of the dimensional, structural and material consistency of the historic buildings and their context is mandatory and can influence the restoration choices. Starting from a recent applied research concerning a significant and symbolic monument of Naples, Castel Nuovo, the paper intends to highlight not only the importance of the integration of the specialist surveys, but also the role of the critical interpretation. The results of the different disciplines involved in the knowledge process have to be evaluated critically in view of the conservation of the tangible and intangible values. Furthermore, catching the complexity of architecture of the past depends on the capacity to maintain a close and constant contact with the building physicality and also on a complex methodology which is inclusive of new interpretative instruments which could increase a virtuous hermeneutic circle.
\end{abstract}

\section{ARCHITECTURAL HERITAGE AND KNOWLEDGE}

Heritage and technologies are currently experiencing euphoric times: they provide each other stimulation and new attractive perspectives of fruition and development The innovative techniques which in these last years have been applied to the cultural heritage are before everyone's eyes: if they, on the one hand, are used to visual simulation with the aim to surprise and astonish by showing entire urban landscapes and daily life scenes of the past, on the other hand the current technology represents an indispensable technical element in handling and managing any kind of cultural heritage. Further, innovative techniques show enormous potentialities from the point of view of knowledge in reference to different operational areas: archiving, detection and processing.

In particular, the survey techniques applied to the heritage conservation reassure us that it is possible to know the building in its entirety and give us the idea of obtaining the real reality of it in a objective manner.

Indeed, the innovative technologic which are adopted for the restoration process, as those of land and satellite topography, digital photogrammetry, 3D scanning, etc., lead to a very deep understanding of the geometrical, dimensional, structural and material consistency of the historical buildings and their context. In many cases, the innovative instruments can record the micro-fractures, microdeformations and finally several elements of decay.

Through the new techniques we can further define, with a real and appropriate accuracy, the present state of the cultural heritage: the state of physical condition of the building can be easily framed; we get micro and macro information; we check the structures through monitoring; we can even appreciate the 'energy' which the material emits thanks to the thermographic testing surveys; we may know the visible and the invisible.

In addition, representations seem to be complete and the layouts appear to return an exhaustive reality of the object. All that it is true but in the case of recording of the historic building we are obliged to consider other factors connoting the heritage identity. This is because the material and the forms are not only physical entities but also historical ones.

\section{THE EXPERIENCE OF AN APPLIED RESEARCH}

In this sense a research experience carried out for the Neapolitan Castel Nuovo has given rise to some issues about the knowledge of a 'monument' in Naples inevitably showing its complex multidimensional reality. The study, which has been carried out inside of a research consortium and technology district (SNECS Project, Social Network of Historical District Entity ${ }^{1}$, addressed the multidisciplinary data collecting in order to generate knowledge models for the generation of the Historic Centers Atlas and, in particular, the production and representation of knowledge which was based both on humanities and technical science. It is about the experimentation of technologies and prototypes for advanced applications of an innovative system of transmission of 'knowledge' through varied technologies as well as the innovative ones based on a simultaneity of various information (audio, visual, etc.), using virtual reality (VR) and augmented reality (AR) applications.

In such particular framework, the survey activities have been based on the integrated studies which had different fields of research. Among the different research unities those of the working groups of INNOVA, DISTAR and that of OR $2.6^{2}$ had

\footnotetext{
${ }^{1}$ It is about the research carried out within the project Social Network of Historical District Entity (SNECS) inside the Technology District DATABENC (Distretto ad Alta Tecnologia dei Beni Culturali) Storici) in collaboration with a lot of Departments of the University of Naples Federico (DiARC, DSU, DiSTAR, DEMI), of CNR (ICARISAFOM-ISSM), and societies as INNOVA scarl and CSP spa. (prof. Aldo Aveta, archh. Raffaele Amore, Claudia Aveta, Marida Salvatori, Gian Paolo Vitelli, prof. Maurizio de' Gennaro).

${ }^{2}$ In the research programme MAST (Maschio Angioino Smart Tour, with Castel Nuovo as demonstrator) within the SNECS Project, the working group INNOVA and DISTAR Federico II University of Naples addressed a study on some curtain walls of the monumental complex; the OR 2.6 (Models of Knowledge for the Generation of the Atlas of the Historical Centers with particular reference to the history of the restorations of Castel Nuovo) of DiARC of the same University, started a survey and data collection of the Castel Nuovo's restorations succeeded over the years. More specifically, it is the result of OR2.6 research "Knowledge models for the generation of the Historic Centers Atlas" coordinated by Bianca Gioia Marino and included in OR2 "Production and representation of knowledge" (Leader Aldo Aveta).
} 
the chance to share their results. The methodology based on the interdisciplinary dialectic led to continually compare the results of a petrophysical characterization have been continually compared with those of the dimensional survey. Similarly, the collected data has been interpreted and compared with the historical information. As it is well known, the contribution of the historian of architecture is one of the main pillar of the methodological structure of knowledge. This kind of integrated methodology has been based on a deep study of transformation of Castel Nuovo and, above all, has presented a complex scenario which gave the chance to interpret and re-read the identity of the monument and, also, to deal with some of the issues of 'knowledge' by using the advanced technologies.

As supported by an extensive bibliography, the current image of the ancient Castle is a complex entity resulting from considerable transformations and numerous and significant renovations which have succeeded one another in the centuries. The interventions at the beginning of the $20^{\text {th }}$ century have reconfigured its forms with the aim to obtain a precise image of the historic monument ${ }^{3}$. The consolidate image of the castle, isolated and characterizing the wide square Piazza Municipio, contributed to enhance its symbolic value for the city of Naples ${ }^{4}$. The building mass of Castel Nuovo is evident to the sight from more and different parts of the city and dialogues with Castel S. Elmo representing a significative bulwark for those who approach it from the sea. It appears unique with its individuality.

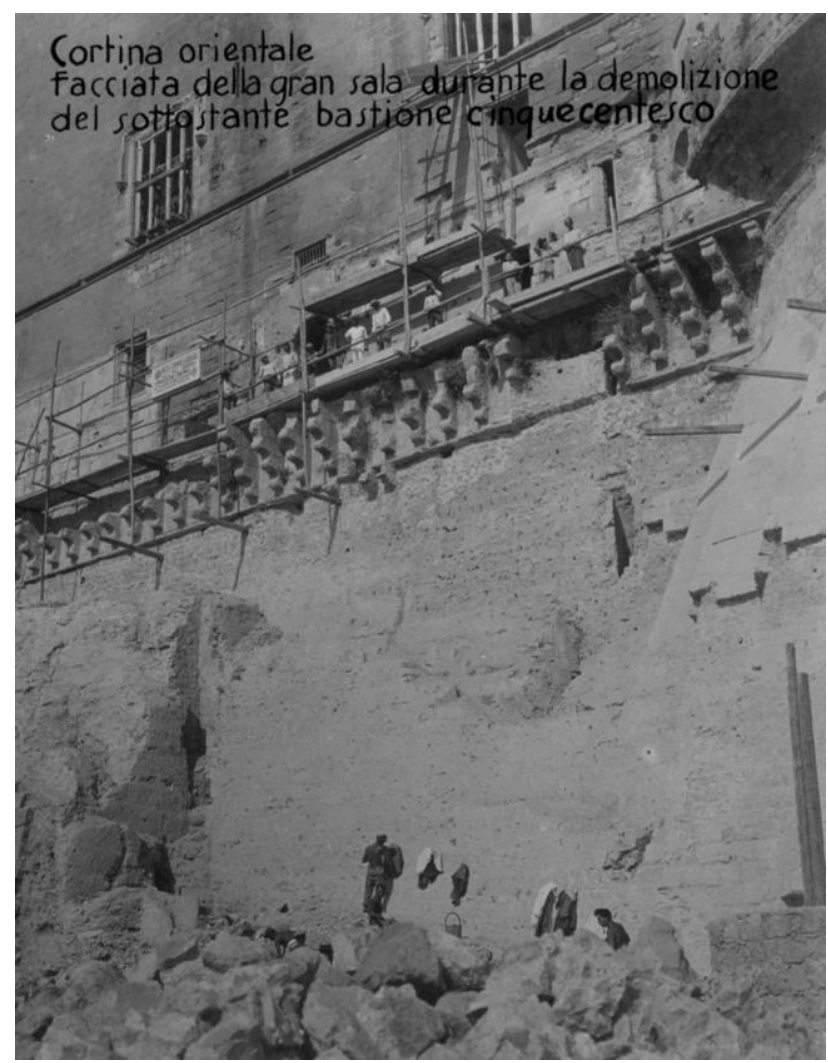

Figure 1. Castel Nuovo, Napoli. Eastern Curtain. Archival photo of the demolition works of the sixteenth-century defensive bastion carried out in the 1930s (Archivio Storico Municipale Comune di Napoli, Album l,

Patrimonio culturale, Castelnuovo prima e dopo i restauri

In fact, the demolition of the ramparts and the attached factories has interrupted the previous integration with the urban pattern which characterised this part of the historic city until the end of the XIX

\footnotetext{
${ }^{3}$ After the municipal decision (1871) all the works executed during the viceregal period were demolished, thus continuing the process of "liberation" of the Castle. ${ }^{4}$ Castel Nuovo (Castrum Novum), built by Carlo d'Angiò in 1279, is one of the four castles of the town and it was realised at the edge of what was the town at that time.
}

century ${ }^{5}$. The project by Riccardo Filangieri di Candida entailed the cancellation of the traces (Figure 1) of the historic architectural layering and, also, consequently of the significance ones that the historical building have had over the times. The restorations of the first decades of the $20^{\text {th }}$ turned the architectural complex back to the original Aragonese testimony ${ }^{6}$ (Figure 2). For years, therefore, neither traces nor memory have remained of the secular transformations after the Aragonese phase, at least until the discovery of the remains of ancient walls and structures under Piazza Municipio, following the construction of the new metro station. Through the interpretation of the restorations followed over the years, including those of the Sixties of the last century, the research activity aimed to identify the characters of its current identity.

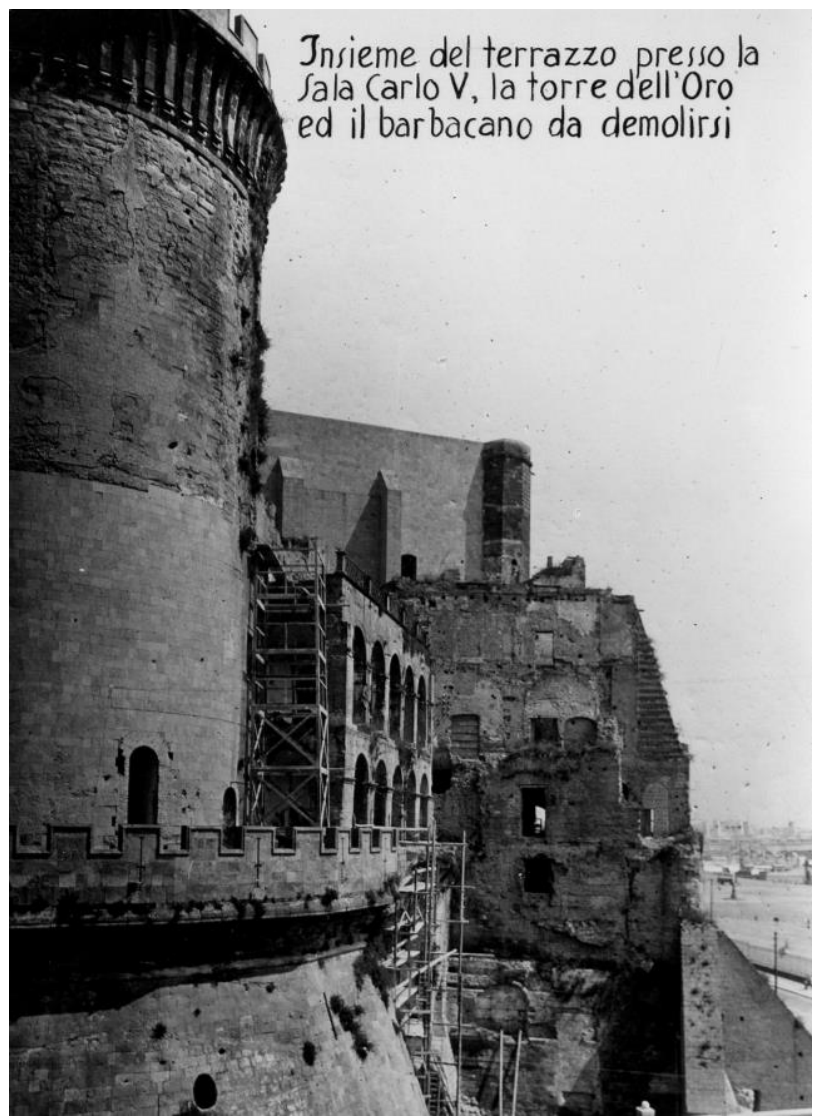

Figure 2. Castel Nuovo. The terrace at the hall Carlo V, the Torre dell'Oro and the barcacane to be demolished. In the foreground we can notice the repairs of the tuff truss performed for the lower part of the

Torre dell'Oro (Archivio Storico Municipale Comune di Napoli, Album 1, Patrimonio culturale, Castelnuovo prima e dopo i restauri).

\section{INNOVATIVE TECHNIQUES AND THE MATERIAL PHENOMENON OF ARCHITECTURE}

Taking into account the radical and complex transformations and also the unavoidable integration of new elements and new materials, realized by Filangieri's interventions (Figure 3) an accurate detection of some external walls and of the masonry presenting interesting features has been carried out. Parallel to the transformations and restoration survey which focused on the numerous elements of the castle that were replaced and/or reintegrated, the orthoprojection of the point cloud by the laser scanner started. This survey with RGB data of high-

${ }^{5}$ See Filangieri, 1926, 1927. In this occasion, the calls the addition to the Castle as «sovrapposizioni informi» and considering its architecture as «esemplare unico di tanta importanza» for the military history, postulated the elimination of all parts which had been added to the Aragonese sample of fortress.

${ }^{6}$ Further we have to remember the restoration of the Arch of Alfonso d'Aragona by Adolfo Avena (Avena, 1908) at the beginning of the XX century. 
resolution photographs taken by the camera connected to the device, allowed to obtain targeted representations of the architectural complex (Figure 4, 5, 6). Therefore a map of the macro - areas for materials and construction techniques and the forms of degradation associated with them has drawn up (Figure 8).

Moreover the use of high definition images and photographic documentation made possible the micro identification of the different materials and techniques, and also the detection of the degradation patterns (Figure 9). On the other hand, the taking and the image processing under diverse lighting conditions has revealed a multiform reality of the building and of its surfaces. Under this point of view, the point cloud processing has focused on the study of material from which some different masonry interventions taken place over time has clearly emerged (Figure 7). In parallel, the results of laboratory tests processed by the petrographic and geochemical working group explained the nature of the material and the reason of its alterations.

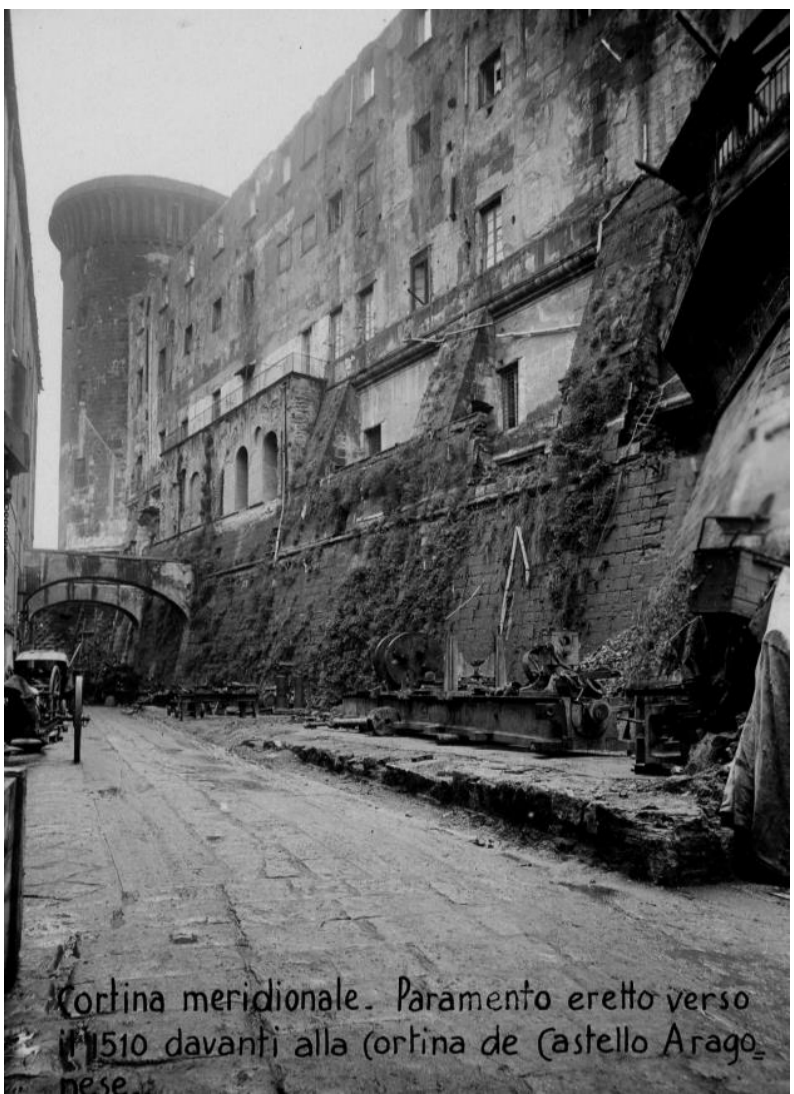

Figure 3. Castel Nuovo Napoli. South curtain, before demolition. Album 1, Patrimonio culturale, Castelnuovo prima e dopo i restauri, Archivio Storico Municipale Comune di Napoli.

The abovementioned research experience carried out for the Neapolitan monument and targeted to collect and systematize the cultural contents to be entered in the interactive data network, according to an ontological structure for a personalized fruition experience, has therefore given the opportunity to interlace the different specializations overcoming the danger of any sort of specialism. In addition, the study revealed unknown aspects that, generally, the Angevin Keep, symbol of the city flattened on its 'finished' and static image of the Aragonese image, does not allow to grasp.

Therefore, through innovative techniques of measurement surveys and targeted laboratory analysis, the heterogeneity, irregularities, brightness variations, degradations, in one word, transformations are detected and identified.

The recording of those data raises the question of heritage complexity. In fact, hence the object of our investigation is heritage, that is an entity representing the collective and individual memory bringing us to the consideration of intangible issues, we should have the understanding of the meanings and values which have been accumulated over time. The 'essence' of the historic building is inside its material and in its alterations; and it is extremely complex to be grasped. The fact that involves issues of intangible nature directly lead us to questions inherent to the monument's identity. Then, in case of conservation plan and of definition of relating technical choices, we have to try to penetrate the identity of the monuments. That makes perfectly clear how fundamental is the dialogue between sciences and humanities.

Indeed, from a certain point of view we cannot avoid to consider the identity of the pre-existing building like the human one ${ }^{7}$. Architecture, as the human being, has an identity marked by its background; it is a register of history ${ }^{8}$ and its material marks the time, it is a layering of historical events. As we can see, this is a highly sensitive issue but also because it involves the general values system of the community.

For this reason, the specific surveys for understanding the cultural heritage - with a view to pursuing the intention to conserve its material and its values - do not have to be the mere application of a protocol of 'knowledge', but they must be addressed and integrated with the historic data collection: representing methodology's first step. Knowledge means opening up to several disciplines to increase an interdisciplinary hermeneutic circle.

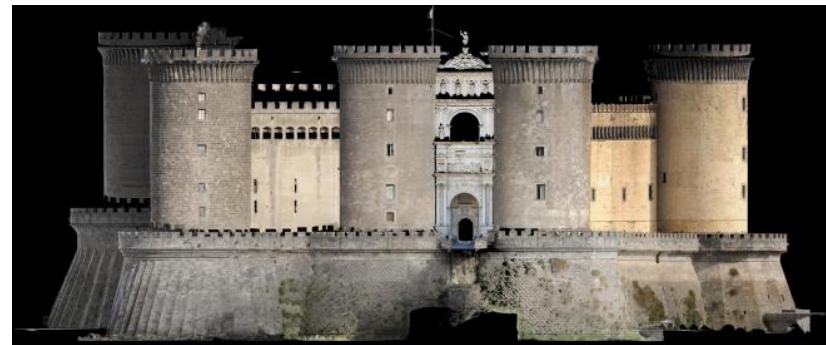

Figure 4. Real West Point Prospect Cloud Orthoprojection. Castel Nuovo.

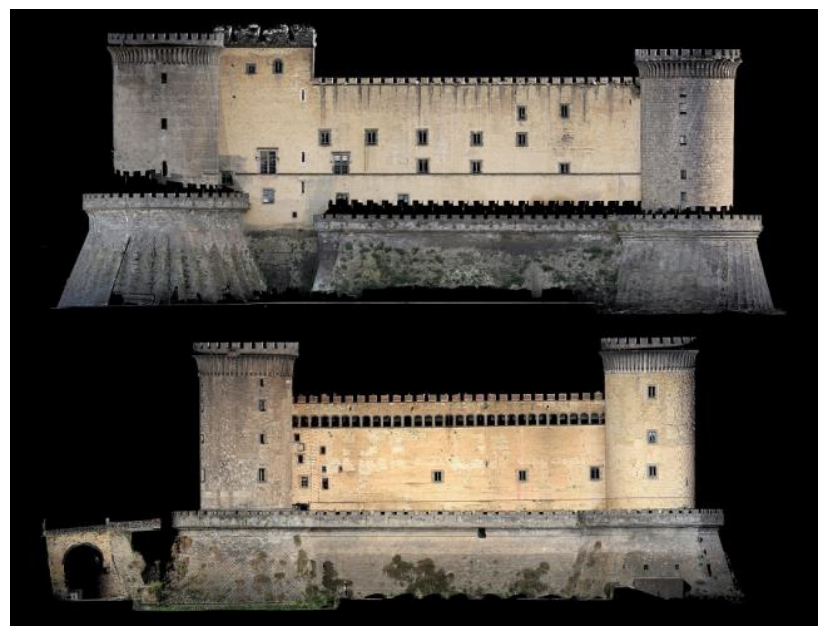

Figure 5. Real North and South Point Prospect Cloud Orthoprojection of Castel Nuovo, Napoli.

\footnotetext{
${ }^{7}$ The interrelationships and structural similarities between heritage of the past and the work of art and the identity of an individual, have been already highlighted in the conservation culture (i.e. Roberto Pane; for a more exhaustive representation of these approaches see Marino, 2010) and also recently in the philosophical thought: "Aside from the traditional eighteenth-century understanding of the artistic and the psychological domains as two aspects of the aesthetic sphere, this thesis (...)" recalls "Dewey's idea of a deep continuity between art and the human experience (see Dewey 1980)". See Ferrara, 1998, p. 16.

${ }^{8}$ Roberto Pane told about "psychological case" (1966), namely the antiquity which is layered in ourselves and which is to be considered as the premise and condition of our fate. And, for this, he founds the legitimacy and need of heritage conservation on the "psychological layering". Human beings find themselves through the "identification" in heritage with every its material historic stratification.
} 


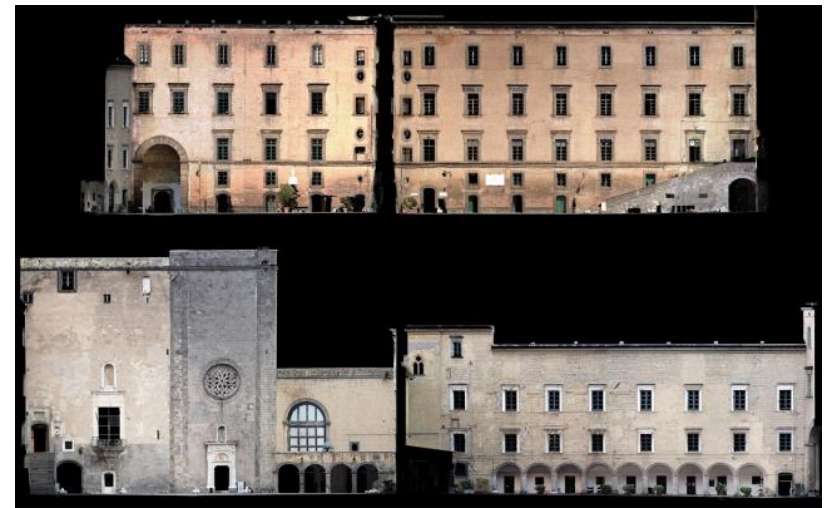

Figure 6. Real orthopedics of the clouds of points of the courtyard prospects of Castel Nuovo, Napoli.

In particular, the restoration research unity (the abovementioned OR 2.6), in systemising the data collection, was aimed to identify a series of documentary values and physical pre-existing features resulted from the transformation processes and restorations ${ }^{9}$. A part from the objective of this research - which was to provide the informative support of the acquired and communicated data - it has to be underlined that it has been based on a continuous cross-reference to the sources, both images and texts. In addition, in confirmation of that fruitful interpretative interdisciplinary circularity, the surveys about the past restoration interventions have been integrated with the results of the historians of architecture, of the instrumental survey and geo-material data. This integrated approach allowed us to appreciate the 'reality' of the monument which shows its complex phenomenology through its stones.

Further, the historic surveys about restoration interventions could direct, in a more critical way, the other specialist surveys inherent to the geo-material and scanner-laser detections.

Indeed, recalling the particular nature of the architectural heritage, one has to recognize that the system of meanings of a historic architecture represents a consistent part of the interdisciplinary knowledge which is based on an interpretative critical process. From this point of view, the iconographic, archival, bibliographic material has to be selected and interpreted for the fruition, and, we hope, for having a correct formulation of conservation actions. In this sense, the definition of a 'knowledge model' for Castel Nuovo has been based on a multidisciplinary work collecting data (images and texts) and considering the monument as well as a multidimensional entity. For this, even though the abundance of documentary material and sources (intervention reports, drawings, pictures, sketches, plans, photos, paintings, historic views, etc.), the data selection addressed to the monument fruition ${ }^{10}$ intended to provide a critical model where the information might stimulate the constant contact with the physicality of the monument and with its historic/material reality.

It is, in fact, important that the fruition of the cultural heritage and the restoration interventions can be based on the richness

\footnotetext{
${ }^{9}$ More specifically, relying on the reports on the restoration works carried out between the late $19^{\text {th }}$ and the early $20^{\text {th }}$ century by Adolfo Avena and Riccardo Filangieri di Candida, as well as on the archival sources and comparative investigation, performed in numerous archives (including the City Historical Archive and the Superintendence Archive).

${ }^{10}$ For an overview of the approaches see A.Aveta, B.G.Marino (2017), R. Amore (2017).
}

of its meanings and on the material authenticity and, above all, on the main purpose to preserve them ${ }^{11}$.

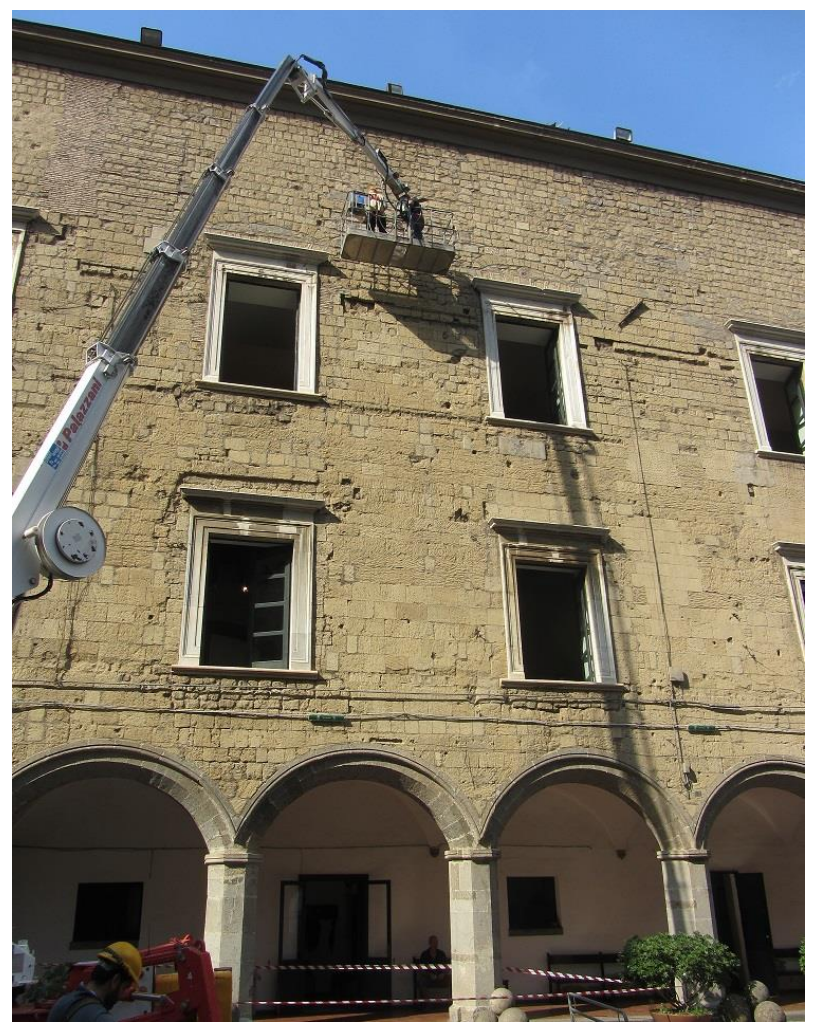

Figure 7. Castel Nuovo, Napoli. The south facade of the inner court: particular of the essays of material made on site.

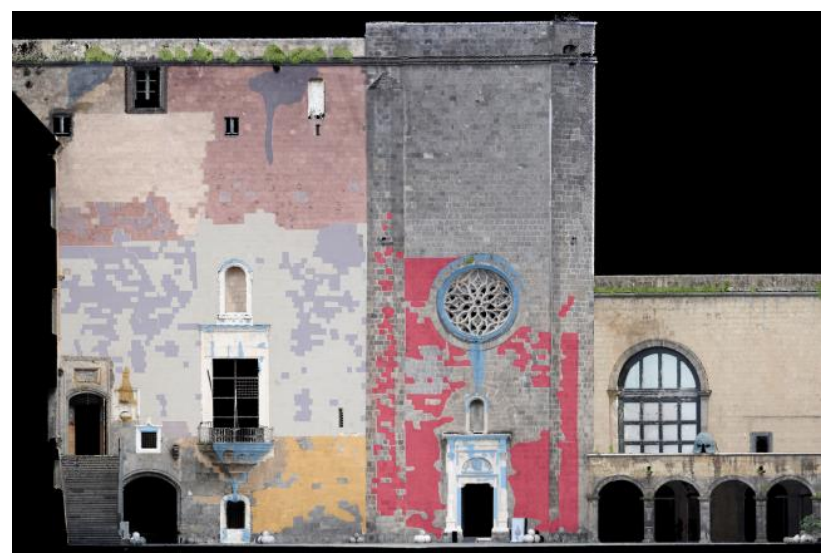

Figure 8. Inner courtyard, facade facing east: orthoprojection of point cloud elaborated by laser scanner, colored with RGB data of photographs with detection for macro areas of degradation phenomena of Castel Nuovo, Napoli.

\footnotetext{
11 The issue of authenticity seems to be currently a real focal point for understanding and also identifying the challenges of the historic heritage and during the twentyth century it has been addressed by several philosophers and experts. In addition, authenticity has very often been considered a 'hub' to understand the present and it has been a topic for the epistemological research. Recent international approaches to this issues have been discussed in the Third Biennial Conference "What does heritage change? Le patrimoine, ça change quoi?", sponsored by ACHS, Association of Critical Heritage Studies (Montreal, Canada, 6 - 10th June 2016). On this occasion, economic, anthropologic, urbanistic, etc. issues were compared in order to identify new frontiers of conservation.
} 


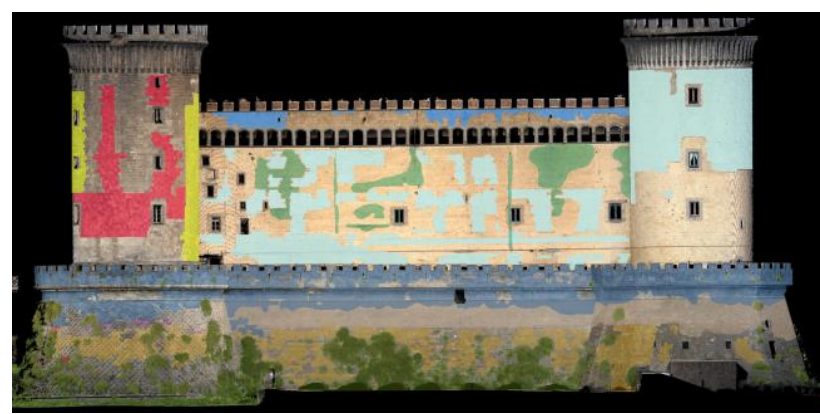

Figure 9. South Curtain: orthoprojection of point clouds processed by the laser scanner, colored with RGB data of photographs with detection for macro areas of degradation phenomena of Castel Nuovo, Napoli.

\section{FOR AN INTERDISCIPLINARY EFFORT: POSSIBLE PERSPECTIVES AND CONCLUDING REFLECTIONS}

The above-mentioned research experience carried out in relation to the Neapolitan Castle has showed the relevant importance of the comparative analysis of the historic iconography as well as artistic representations, ancient engraving, surveys, graphs, photographs and films preserved in several archives: this allowed the reconstructing of the history of transformations and conducted the laser-scanner for further detailed study in a more appropriate way.

Moreover, the contribution of the appreciable introspective and cognitive potentials offered by the innovative technologies gives us new interpretative models.

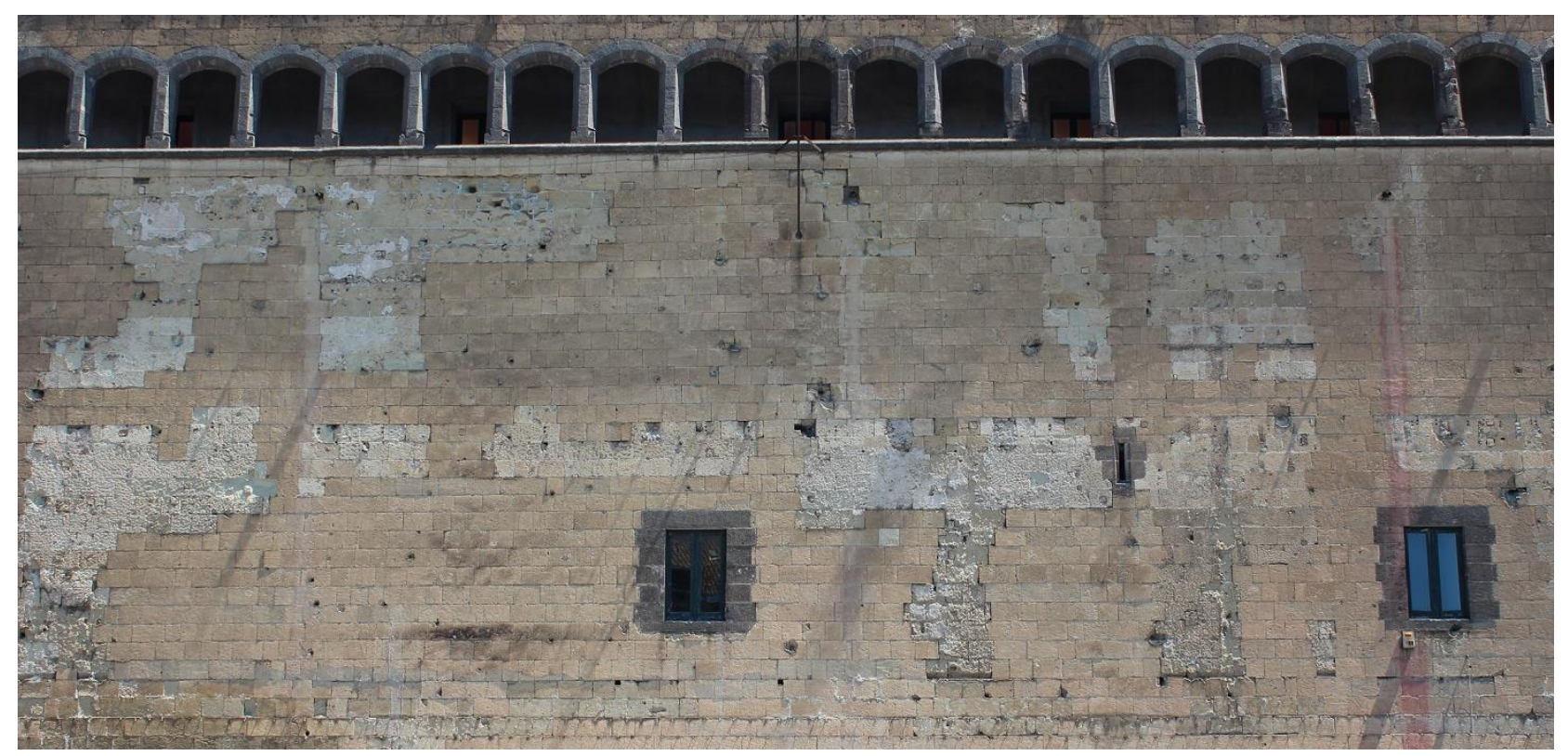

Figure 10. Castel Nuovo, Napoli. South Curtain: phenomenon of alveolization and retraction for erosion of the tuff surface. Unlike the uniformity connoting the image of the Castle, the walls show the heterogeneity of their surfaces which have been highlighted by specific representations.

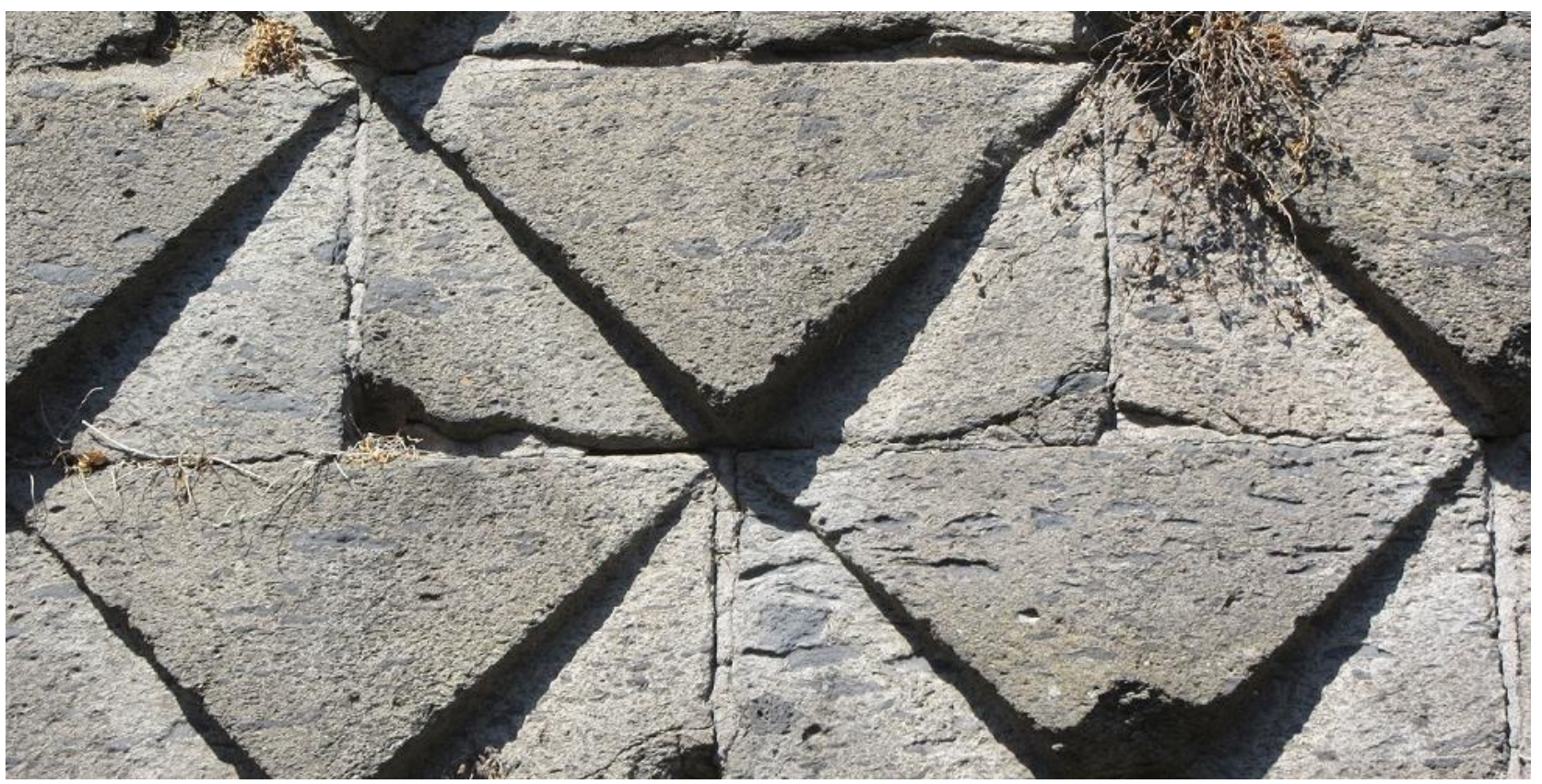

Figure 11. Castel Nuovo, Napoli. The coating in Piperno of Torre della Guardia. The particular scale technique of the tower base. 


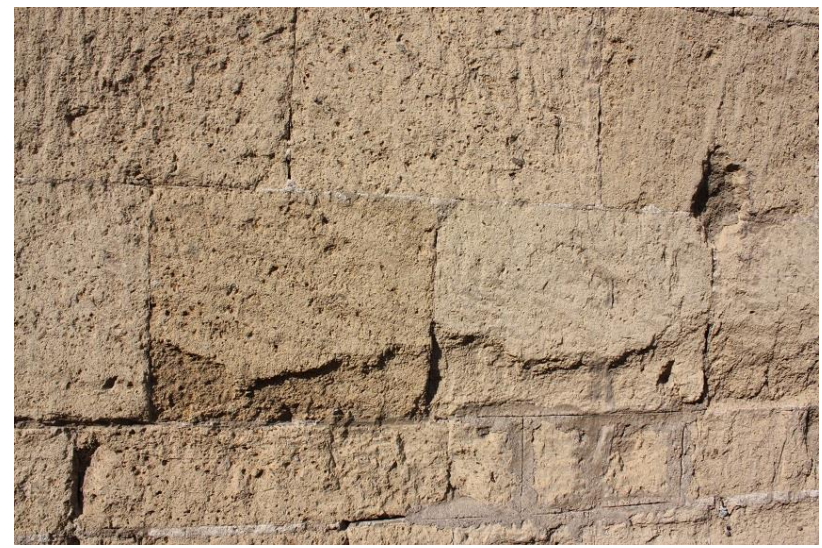

Figure 12. Castel Nuovo, Napoli. Internal court, southern perspective: phenomenon of alveolization and retraction for erosion of the tuff surface.

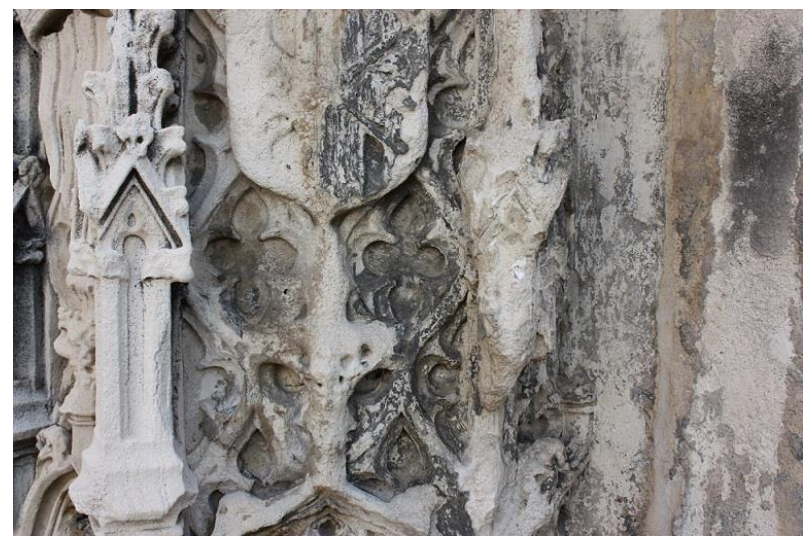

Figure 13. Castel Nuovo, Napoli. Internal court, near the entrance of Gran Sala, the detail of the degradation of marble decorations.

In fact, thanks to the innovative technologies we are able to understand the more complex interaction between the building and its ambiance, as well as its reactions to the lighting and atmospheric conditions.

With the support of these kinds of instruments it has been possible to appreciate the nature of transformations and also identify in a historical-critical manner the different typologies of degradations/alterations.

In particular, we have been able to verify that the use of the laser scanner technology allows to obtain a sort of 'reality mapping'. And its usefulness consists of not only the continuous dialogue with other specialist information, but also and above all, with the physical and close contact with the masonry and material to be investigated.

But, such a change of scale has developed a new perceptive sensibility which drives us to appreciate material in its micro dimension and, therefore, its documentary dimension much more than the mere perception of the monument considered as an object as such.

So this specific approach, the comparative fieldwork and the contact with the physical reality of the building allows the acquisition of the most significant peculiarities of the building structure: the transformation phenomenology which represents the main element both for the monument in itself and for the restoration project, provided its aim is to preserve its authenticity.

We believe that this represents the focal point of the cultural heritage conservation and the borderline between knowledge and restoration intervention. The possibility to have, through the more or less complex point clouds, the imaging of the deformations of a façade, or of reflectance parameters of the masonry, or even the amount of the emissivity of the surfaces and walls, could materially affect our interpretations and, consequentially, the conservative approach. All of this leads to increasing the aesthetic sensitivity of the transformation factors. If we have the aim of preserving the material authenticity and also respecting the authenticity of values which are embodied in heritage, one is led to the consciousness that the fact-finding investigations frame has to be properly assessed through the filter of a complex methodology which includes the tangible and the intangible factors.

We hope that beyond the touristic tours based on legends and hidden mysteries to be discovered in Castel Nuovo ${ }^{12}$, the 'knowledge' might mislead the users to recognize the historic events which allow to understand a civilization.

We cannot fail to see, in the field of cultural heritage, how the integrated surveying and documenting drive us to consider the value of the infinite diversity of a facing wall instead of its uniformity, and also, to record the smallest traces of history which have been impressed in every architecture.

Such methodological attitude provides, through a cooperation among the disciplines, not only to an in-depth understanding of the architecture and of its structural or of its decorative elements, but also it redirects the restoration design to a more conservative vision of its objectives.

The restoration plan is an architectural project, a project of a particular kind of architecture. It is a project that has to be inclined to the alignment between two realities: that of the existing present state and that of the future.

We cannot deny that, in the field of new surveying techniques for the cultural heritage, the borders have been opened and new theoretical and practical perspectives are in front of us. It is important to have a inter-disciplinary - not a multi-disciplinary - outlook trying to improve the integration of different representation techniques and technologies by improving activities for new forms of layout, new skills based on the strong cooperation between survey and restoration experts.

Actually, in order to plan a research experience for an experimental methodology for the restoration plan, we are trying to develop and identify planning methods and methodologies based on the real process of representation and interpretation ${ }^{13}$. Indeed many disciplines, among which aesthetics and social sciences and humanities, should be involved in critical process of interpretation to support, in a interdisciplinary way, the direction of the conservation plan ${ }^{14}$.

In this sense, the cross-disciplinary approach represents the real tool for increasing the fertile hermeneutic circle needed to guarantee the authentic preservation of historic materials and the strategic directives of the cultural heritage conservation and enhancement. In the same manner, the cross of survey findings and the characterization of materials and structural components has led to the individuation of the complexity of architecture, underlining its richness and its identity and, among others,

\footnotetext{
${ }^{12}$ It is about the Saint Graal legend linked to the Sala dei Baroni publicised by the touristic operators.

${ }^{13}$ It is about a research programme under a framework agreement with the Cortona Municipality ("Across the stones: images, landscape and memory for an interdisciplinary knowledge and the enhancement of the Fortress") and referred to a series actvities to experiment a conservation methodology based on a interdisciplinary interpretation of the Girifalco Fortress.

${ }^{14}$ The above mentioned experimental experience intends therefore to improve some interdisciplinary activities in order to the knowledge, interpretation (data gathering), representation (layout data), and digitalization of complex data.
} 
influencing the choice of what and why has to be preserved and communicated by the conservation plan.

The aim is to integrate the traditional and innovative survey techniques of cultural heritage with different forms of visual interpretations as photograph and videos.

This approach would allow to create that "cross-disciplinary arena" where it is possible to share visions and perspectives.

In fact, to address these challenges many disciplines have to work jointly to create new conceptual, theoretical, methodological strategies, that integrate and move beyond discipline-specific approaches.

Maybe we should try to work through a trans-disciplinary perspective.

\section{REFERENCES}

Aa.Vv., 2008. Diagnostica e conservazione. L'insula 14 del Rione Terra, a cura di A. Aveta, Napoli.

Amore, R., 2017. Castel nuovo: materiali dei restauri e restauro dei materiali (Old and new materials to the restoration of Castel Nuovo). In A.Aveta (a cura di), Castel Nuovo in Napoli. Ricerche integrate e conoscenza per il progetto di restauro e valorizzazione, Artpaparo edizioni, Napoli.

Avena, A, 1908. Il restauro dell'Arco d'Alfonso d'Aragona in Napoli, Danesi, Roma.

Aveta, A., Marino, B.G., 2017. La fruizione come problema di conservazione: la sperimentazione di un modello critico per la valorizzazione di Castel Nuovo (Fruition as conservation issue: an experimentaion of a critical model for the valorization of Castel Nuovo). In A. Aveta (a cura di), Castel Nuovo in Napoli. Ricerche integrate e conoscenza per il progetto di restauro e valorizzazione, Artpaparo edizioni, Napoli.

Aveta A., Marino B.G., Vitelli G.P., 2011. Realtà, verità ed interpretazione dell'architettura storica: frontiere e prospettive dei contemporanei strumenti di rilevamento. In M.L. Papa (a cura di), Il disegno delle trasformazioni, Atti delle Giornate di Studio "Il disegno delle trasformazioni”" (Napoli, 1-2 dicembre 2011), Clean Edizioni, Napoli.

Calcaterra D., Cappelletti P., Langella A., Morra V., Colella A., de' Gennaro R., 2000. The building stones of the ancient centre of Naples (Italy): Piperno from R. Campi Flegrei. A contribution to the knowledge of a long-time-used stone, in «Journal of Cultural Heritage» n.1, pp. 415-427.

Calcaterra D., Cappelletti P., Colella A., de' Gennaro R., Langella A., de Gennaro M. 2003. Le pietre dell'architettura storica della Campania, in «ARKOS», nuova serie, n. 4 (2), pp. 40-46.

de' Gennaro M., Fuscaldo M.D., Colella C., 1993. Weathering mechanisms of monumental tuffstone masonries in downtown Naples, in «Science and Tecnology for Cultural Heritage», pp. 53-62.

de' Gennaro M., Calcaterra D., Langella A. (a cura di), 2013. Le Pietre Storiche della Campania, dall'Oblio alla Riscoperta, Luciano Editore, Napoli.

Fancelli, P., 1997. L'entità veritativa dello stato di fatto monumentale, in «ANANKH» n.19, pp. 22-28.

Ferrara A. 1998, Reflective Authenticity. Rethinking the project of Modernity, Routledge, New York.

Filangieri R. (a cura di) 1926. Commissione per l'isolamento e il restauro di Castel Nuovo, Relazione sui criteri per un piano generale di restauro, Stabilimento Industrie Editoriali Meridionali, Napoli.

Filangieri R., 1927. Castel Nuovo e i suoi restauri, Conferenza tenuta presso la Compagnia degli Illusi il 19 dicembre 1926, estratto dal n. 5 del «Bollettino del Comune di Napoli», maggio 1927, Tipografia Francesco Giannini e figli, Napoli.

Marino, B.G., 2006. Restauro e autenticità. Nodi e questioni critiche, Edizioni Scientifiche Italiane, Napoli.

Marino, B.G., 2009. Una diagnostica per $i$ valori materiali ed immateriali: la conservazione della Chiesa rupestre di S. Maria di Piedigrotta a Pizzo Calabro. In Aa.Vv., La diagnostica per il restauro del patrimonio culturale, Napoli, pp. 285-294.

Marino, B.G., 2010. Luoghi esterni, immagini interne: attualità del percorso della conservazione dell'architettura. In Roberto Pane tra storia e restauro. Architettura, città paesaggio, Atti del Convegno Nazionale di Studi, Napoli, 27-28 ottobre 2008, a cura di S. Casiello, A. Pane, V. Russo, Marsilio Editore, Venezia 2010, pp. 149-153.

Marino B.G., 2012. La materia dell'architettura, l'architettura della materia, in Aveta A., Marino B.G. (a cura di), Restauro e riqualificazione del centro storico di Napoli patrimonio dell'UNESCO tra conservazione e progetto, Edizioni Scientifiche Italiane, Napoli, pp. 97-119.

Marino B.G., 2017. Restauro, storia, progetto: una questione da affrontare. In RICerca/REStauro. Questioni teoriche: inquadramento generale, a cura di S. Musso. Edizioni Quasar, Roma, pp. 87-95.

Marino B.G., 2017. Restauri storici e valori contemporanei: immaginazione e memoria delle trasformazioni di per la fruizione di Castel Nuovo (Historic restorations and contemporary values: imagination and memory of the transformations for the Castel Nuovo fruition. In A.Aveta (a cura di), Castel Nuovo in Napoli. Ricerche integrate e conoscenza per il progetto di restauro e valorizzazione, Artpaparo edizioni, Napoli.

Silberman N., 2015. Remembrance of things past: collective memory, sensory perception and the emergence of new interpretive paradigms, in A. Castillo Mena (ed. by), In Second International Conference on best Practices in World Heritage: People and Communities, Universidad Complutense de Madrid, Madrid. 